\title{
Adjuvanting Allergen Extracts for Sublingual Immunotherapy: Calcitriol Downregulates CXCL8 Production in Primary Sublingual Epithelial Cells
}

\begin{abstract}
Michael P. Pelst ${ }^{1}$, Clara Höbart ${ }^{2}$, Charlotte Wallaeys ${ }^{3,4}$, Hilde De Rooster ${ }^{5}$, Yannick Gansemans ${ }^{6}$, Filip Van Nieuwerburgh ${ }^{6}$, Bert Devriendt ${ }^{1}$ and Eric Cox ${ }^{1 *}$

${ }^{1}$ Laboratory of Immunology, Department of Virology, Parasitology and Immunology, Faculty of Veterinary Medicine, Ghent University, Merelbeke, Belgium, ${ }^{2}$ Center of Physiology and Pharmacology, Medical University of Vienna, Vienna, Austria, ${ }^{3}$ VIB Center for Inflammation Research, Ghent, Belgium, ${ }^{4}$ Department of Biomedical Molecular Biology, Ghent University, Ghent, Belgium, ${ }^{5}$ Small Animal Department, Faculty of Veterinary Medicine, Ghent University, Merelbeke, Belgium, ${ }^{6}$ Laboratory for Pharmaceutical Biotechnology, Faculty of Pharmaceutical Sciences, Ghent University, Ghent, Belgium
\end{abstract}

Application of allergens onto the sublingual epithelium is used to desensitize allergic individuals, a treatment known as sublingual immunotherapy. However, the response of sublingual epithelial cells to house dust mite allergen and potential tolerance-promoting adjuvants such as Toll-like receptor (TLR) ligands and calcitriol has not been investigated. In order to study this, primary sublingual epithelial cells were isolated from dogs and cultured in vitro. After 24-h incubation with a Dermatophagoides farinae extract, a Dermatophagoides pteronyssinus extract, TLR2 ligands (FSL-1, heat-killed Listeria monocytogenes, Pam3CSK4), a TLR3 ligand (poly l:C), a TLR4 ligand [lipopolysaccharide (LPS)], and calcitriol (1,25-dihydroxyvitamin $\left.D_{3}\right)$, viability of the cells was analyzed using an MTT test, and their secretion of interleukin 6 (IL-6), IL-10, CXCL8, and transforming growth factor $\beta 1$ (TGF- $\beta 1$ ) was measured by enzyme-linked immunosorbent assay. Additionally, to evaluate its potential effect as an adjuvant, sublingual epithelial cells were incubated with calcitriol in combination with a $D$. farinae extract followed by measurement of CXCL8 secretion. Furthermore, the effect of $D$. farinae and calcitriol on the transcriptome was assessed by RNA sequencing. The viability of the sublingual epithelial cells was significantly decreased by poly I:C, but not by the other stimuli. CXCL8 secretion was significantly increased by $D$. farinae extract and all TLR ligands apart from LPS. Calcitriol significantly decreased CXCL8 secretion, and coadministration with $D$. farinae extract reduced CXCL8 concentrations to levels seen in unstimulated sublingual epithelial cells. Although detectable, TGF- $\beta 1$ secretion could not be modulated by any of the stimuli. Interleukin 6 and IL-10 could not be detected at the protein or at the mRNA level. It can be concluded that a $D$. farinae extract and TLR ligands augment the secretion of the proinflammatory chemokine CXCL8, which might interfere with sublingual desensitization. On the other hand, CXCL8 secretion was reduced by coapplication of calcitriol and a $D$. farinae extract. Calcitriol therefore seems to be a suitable candidate to be used as adjuvant during sublingual immunotherapy.

Keywords: sublingual, epithelium, Dermatophagoides farinae, Toll-like receptor, calcitriol, CXCL8, dog, sublingual immunotherapy 


\section{INTRODUCTION}

Allergen-specific immunotherapy (ASIT) is currently the only therapy able to alter the immunopathological reactions during allergies, teaching the immune system to tolerate the specific allergen (1). Sublingual immunotherapy (SLIT) is a form of ASIT during which allergens are administered under the tongue onto the sublingual epithelium $(2,3)$. Epithelial cells are known to be immunologically responsive and to influence the behavior of surrounding immune cells. For instance in allergic disease, epithelial cells can secrete interleukin 25 (IL-25), IL33 , and thymic stromal lymphopoietin (TSLP), which promote proallergenic responses $(4,5)$. House dust mites are one of the most important allergen sources, causing respiratory allergies in humans (6) and atopic dermatitis in dogs (7). House dust mite allergens are known to interact with Toll-like receptors (TLRs) and protease-activated receptors expressed by epithelial cells. This induces proinflammatory and proallergenic mediator production in human airway epithelial and epidermal cell cultures (8-11) and contributes to disease development in mouse asthma models (12-14). However, whether sublingual epithelial cells are responsive to house dust mite allergen extracts has not been assessed.

During SLIT, the use of tolerance-promoting adjuvants has been suggested to improve the number of successfully treated patients and to expedite the clinical onset of allergenspecific desensitization (15). Toll-like receptor ligands have been proposed as such adjuvants. In a mouse asthma model, sublingual coadministration of an antigen and the synthetic TLR2 ligand Pam3CSK4 decreased airway hyperresponsiveness and reduced antigen-specific $\mathrm{T}$ helper $2\left(\mathrm{~T}_{\mathrm{H}} 2\right)$ responses in the draining cervical lymph nodes (16). In addition, ex vivo exposure of human peripheral blood mononuclear cells to TLR2 ligands reduced their IL-5, IL-13, and immunoglobulin E (IgE) production $(17,18)$, suggesting a suppressing effect of TLR2 ligands on $\mathrm{T}_{\mathrm{H}}$ 2-mediated responses. Apart from TLR2, TLR4 ligands were reported to have a beneficial effect during ASIT for pollen allergy, improving clinical symptoms and inducing protective allergen-specific IgG antibodies in humans (19). The most active form of vitamin $\mathrm{D}_{3}$, calcitriol (1,25-dihydroxyvitamin $\left.\mathrm{D}_{3}\right)$, has also been proposed as adjuvant for SLIT. It was shown to stimulate the production of the anti-inflammatory cytokine IL-10 in human and mouse dendritic cells $(20,21)$ and to induce intracellular FoxP3 expression in T lymphocytes, a transcription factor expressed by tolerance-promoting regulatory $\mathrm{T}$ cells (22). During SLIT, adjuvants are directly applied onto the sublingual epithelium; still, the effect of TLR ligands and calcitriol on the activity of sublingual epithelial cells has not been investigated.

To evaluate whether extracts of house dust mites can modulate immune responses in canine primary sublingual epithelial cells and to evaluate the effect of potential adjuvants during SLIT, sublingual epithelial cells were isolated from biopsies, cultured, and characterized, and the effect of allergens, TLR ligands and calcitriol on the viability, cytokine production, and gene expression by these cells was assessed.

\section{MATERIALS AND METHODS}

\section{Isolation of Canine Primary Sublingual Epithelial Cells and Sublingual Subepithelial Cells}

Sublingual biopsies of $\sim 0.5 \times 0.5 \mathrm{~cm}$ were sampled within $3 \mathrm{~h}$ after euthanasia from six privately owned dogs that were euthanized for medical reasons unrelated to the study (Supplementary Table A). Oral consent to use the corpse for scientific purposes was given by all dog owners. Of one dog, one-half of the sublingual biopsy was processed for immunohistochemistry. This sample was submerged in Methocel $^{\circledR}$ MC (Merck, Burlington, MA, USA), snap-frozen in liquid nitrogen, and stored at $-80^{\circ} \mathrm{C}$. To isolate sublingual cells, biopsies were briefly submerged in $70 \%$ ethanol, washed three times with $\mathrm{Ca}^{2+}$-free and $\mathrm{Mg}^{2+}$-free Dulbecco phosphatebuffered saline (DPBS; Thermo Fisher Scientific, Waltham, MA, USA) and incubated in $4 \mathrm{mg} / \mathrm{mL}$ Dispase II (Thermo Fisher Scientific) in DPBS on ice. After 16- to 24-h incubation, the epithelial layer was carefully separated from the underlying subepithelial tissue, followed by incubation of the epithelial and subepithelial tissue in DPBS with $0.25 \%$ trypsin (Thermo Fisher Scientific) and $2.65 \mathrm{mM}$ EDTA for $20 \mathrm{~min}$ at room temperature (RT; $18^{\circ} \mathrm{C}-22^{\circ} \mathrm{C}$ ). Subsequently, cell suspensions were resuspended, trypsin was neutralized with an equal volume of $5 \%$ fetal calf serum (FCS) (Merck) in DPBS, and the cells were filtered over a $70-\mu \mathrm{m}$ cell strainer (Merck). After centrifugation $\left(400 \mathrm{~g}, 10 \mathrm{~min}, 18^{\circ} \mathrm{C}\right)$, cells were counted and $2.5 \times 10^{5}$ cells $/ \mathrm{cm}^{2}$ were seeded in a culture flask in sublingual epithelial cell culture medium [SECCM; 3/4 Dulbecco modified eagle medium (DMEM), 1/4 nutrient mixture F12-Ham [Thermo Fisher Scientific], 5\% FCS, $2 \mathrm{nM} \mathrm{3,3',5-triiodo-L-thyronine} \mathrm{sodium} \mathrm{salt,}$ $5 \mu \mathrm{g} / \mathrm{mL}$ recombinant human insulin, $10 \mathrm{ng} / \mathrm{mL}$ recombinant human epidermal growth factor, $0.4 \mu \mathrm{g} / \mathrm{mL}$ hydrocortisone, $100 \mathrm{nM}$ L-isoproterenol hydrochloride [Merck], $100 \mathrm{U} / \mathrm{mL}$ penicillin, $100 \mu \mathrm{g} / \mathrm{mL}$ streptomycin, and $100 \mu \mathrm{g} / \mathrm{mL}$ gentamicin [Thermo Fisher Scientific]) (23, 24). During the first 7 days of culture, the SECCM was supplemented with $2.5 \mu \mathrm{g} / \mathrm{mL}$ amphotericin B (Thermo Fisher Scientific), and medium was changed daily. Thereafter, medium was replaced every 2 to 3 days. Cells were expanded, split (0.25\% trypsin, $1 \mathrm{mM}$ EDTA in DPBS) at 70 to $90 \%$ confluence, and used at passages 2 to 7 for the experiments. The sublingual epithelial cells were shown to be free of Mycoplasma infection during routine testing using the LookOut ${ }^{\circledR}$ Mycoplasma PCR Detection Kit (Merck) according to the manufacturer's instructions.

\section{Immunofluorescence Staining of Sublingual Tissue}

Cryosections $(10 \mu \mathrm{m})$ of the frozen tissue (LEICA CM3050 S Microtome; Leica, Wetzlar, Germany) on APES-coated glass slides were fixed in acetone for $10 \mathrm{~min}$ at $-20^{\circ} \mathrm{C}$ and stained to assess the expression of the integrin subunit $\alpha 6$ (CD49f). In subsequent steps, slides were incubated with PBS $+1 \%$ bovine serum albumin (BSA) $+5 \%$ goat serum (Merck) at RT for $30 \mathrm{~min}$, with $10 \mu \mathrm{g} / \mathrm{mL}$ rat anti-human CD49f 
(NKI-GoH3, Thermo Fisher Scientific) or the rat IgG2a antiKLH control (isotype control; Biolegend, San Diego, CA, USA) for $1 \mathrm{~h}$ and with fluorescein isothiocyanate (FITC)-conjugated goat anti-rat IgG (Merck) for $1 \mathrm{~h}$. In between each step, slides were washed with PBS supplemented with $1 \%$ BSA. Counterstaining of the nuclei occurred with Hoechst (Thermo Fisher Scientific). Slides were analyzed using a Leica Leitz DMR fluorescence microscope (Leica). Images were processed using ImageJ (25).

\section{Flow Cytometry}

Sublingual epithelial or subepithelial cells $\left(5.0 \times 10^{4}\right)$ were added to conical bottomed wells of a 96-well plate. Ten $\mu \mathrm{g} / \mathrm{mL}$ rat antihuman CD49f or isotype control in PBS $+1 \%$ BSA was added in a volume of $50 \mu \mathrm{L}$ for $20 \mathrm{~min}$ on ice. Washing of the cells was followed by addition of $50 \mu \mathrm{L}$ of $0.6 \mu \mathrm{g} / \mathrm{mL}$ Alexa Fluor ${ }^{\circledR} 647-$ conjugated goat anti-rat IgG (Biolegend) in PBS $+1 \%$ BSA for $20 \mathrm{~min}$ on ice. After two washing steps, cells were resuspended in $100 \mu \mathrm{L}$ DPBS and analyzed by flow cytometry (CytoFLEX; Beckman Coulter, Brea, CA, USA) using the CytExpert 2.0 software (Beckman Coulter). Singlets were gated in a forward scatter area and height plot, followed by discrimination of cell debris in a forward- and side-scatter plot. Expression of CD49f was assessed by measuring the relative fluorescence intensity for Alexa Fluor ${ }^{\circledR} 647$.

\section{Stimulation of Canine Primary Sublingual Epithelial Cells With House Dust Mite Extracts, TLR Ligands, and Calcitriol}

Canine primary sublingual epithelial cells were seeded in SECCM in a 24-well plate at 30,000 cells/well and incubated overnight at $37^{\circ} \mathrm{C}$ and $5 \% \mathrm{CO}_{2}$. Thereafter, a Dermatophagoides farinae extract, a Dermatophagoides pteronyssinus extract, TLR ligands, calcitriol, or control medium was added for $24 \mathrm{~h}$ to the cultured cells; the supernatant was collected and stored at $-20^{\circ} \mathrm{C}$. The products, listed in Table 1, were added in a volume of 400 $\mu \mathrm{L}$ serum-free sublingual epithelial cell stimulation medium (SECSM) (3/4 DMEM, 1/4 Ham's F-12, $100 \mathrm{U} / \mathrm{mL}$ penicillin, $100 \mu \mathrm{g} / \mathrm{mL}$ streptomycin, and $100 \mu \mathrm{g} / \mathrm{mL}$ gentamicin). The $D$. farinae and $D$. pteronyssinus extracts were prepared by the manufacturer (Greer Laboratories, Lenoir, NC, USA) by crushing whole mite bodies followed by a bilevel extraction at 1:10 and $1: 5 \mathrm{wt} / \mathrm{vol}$ in $0.125 \mathrm{M}$ ammonium bicarbonate and dialysis against distilled water. Because calcitriol was dissolved in ethanol, the control wells for calcitriol contained an equal volume of this solvent. To analyze the effect of the $D$. farinae extract in combination with calcitriol, cells were incubated without stimulus, with $20 \mu \mathrm{g} / \mathrm{mL} D$. farinae extract, or with both $D$. farinae extract and $0.1 \mu \mathrm{M}$ calcitriol in SECSM. Additionally, after 6-h incubation with $0.1 \mu \mathrm{M}$ calcitriol and $20 \mu \mathrm{g} / \mathrm{mL} D$. farinae extract, sublingual epithelial cells were lysed in RLT buffer (RNeasy mini kit; Qiagen, Hilden, Germany) and stored at $-80^{\circ} \mathrm{C}$.

\section{MTT Assay}

An MTT assay was used to evaluate the effect of the different stimuli on the viability and metabolic activity of canine primary
TABLE 1 | Products added to the canine primary sublingual epithelial cells.

\begin{tabular}{|c|c|c|c|}
\hline $\begin{array}{l}\text { Group of } \\
\text { products }\end{array}$ & $\begin{array}{l}\text { Name (specific } \\
\text { receptor) }\end{array}$ & $\begin{array}{l}\text { Working } \\
\text { concentration }\end{array}$ & Supplier \\
\hline \multirow[t]{2}{*}{$\begin{array}{l}\text { Allergen } \\
\text { extract }\end{array}$} & $\begin{array}{l}\text { Dermatophagoides } \\
\text { farina (XPB81D3A2.5, } \\
\text { lot: } 307244)\end{array}$ & $\begin{array}{l}20 \mu \mathrm{g} \text { dry } \\
\text { protein weight } \\
\text { (bradford } \\
\text { assay)/mL } \\
(2.1 \mu \mathrm{g} / \mathrm{mL} \\
\text { Derf 1) }\end{array}$ & $\begin{array}{l}\text { Greer laboratories, } \\
\text { Lenoir, NC, USA }\end{array}$ \\
\hline & $\begin{array}{l}\text { Dermatophagoides } \\
\text { pteronyssinus } \\
\text { (XPB82D3A2.5, } \\
\text { lot: 346230) }\end{array}$ & $\begin{array}{l}20 \mu \mathrm{g} \text { dry } \\
\text { protein weight } \\
\text { (bradford } \\
\text { assay) } / \mathrm{mL} \\
(0.58 \mu \mathrm{g} / \mathrm{mL} \\
\text { Der p 1) }\end{array}$ & \\
\hline \multirow[t]{6}{*}{ TLR ligands } & FSL-1 (TLR2) & $1 \mu \mathrm{g} / \mathrm{mL}$ & $\begin{array}{l}\text { Invivogen, San } \\
\text { Diego, CA, USA }\end{array}$ \\
\hline & $\begin{array}{l}\text { Heat-killed Listeria } \\
\text { monocytogenes } \\
\text { (HKLM) (TLR2) }\end{array}$ & $10^{8} \mathrm{cells} / \mathrm{mL}$ & \\
\hline & Pam3CSK4 (TLR2) & $1 \mu \mathrm{g} / \mathrm{mL}$ & \\
\hline & $\begin{array}{l}\text { Polyinosinic:polycytidylic } \\
\text { acid high molecular } \\
\text { weight (poly I:C HMW) } \\
\text { (TLR3) }\end{array}$ & $10 \mu \mathrm{g} / \mathrm{mL}$ & \\
\hline & $\begin{array}{l}\text { Polyinosinic:polycytidylic } \\
\text { acid low molecular } \\
\text { weight (poly I:C LMW) } \\
\text { (TLR3) }\end{array}$ & $10 \mu \mathrm{g} / \mathrm{mL}$ & \\
\hline & $\begin{array}{l}\text { LPS (Escherichia coli } \\
\text { K12) (TLR4) }\end{array}$ & $10 \mu \mathrm{g} / \mathrm{mL}$ & \\
\hline Vitamin D & $\begin{array}{l}\text { Calcitriol (vitamin D } \\
\text { receptor) }\end{array}$ & $1-0.01 \mu \mathrm{M}$ & $\begin{array}{l}\text { Merck, Burlington, } \\
\text { MA, USA }\end{array}$ \\
\hline
\end{tabular}

sublingual epithelial cells. Five thousand cells/well in $200 \mu \mathrm{L}$ SECCM were seeded in wells of a 96-well cell culture plate. After overnight incubation at $37^{\circ} \mathrm{C}$ and $5 \% \mathrm{CO}_{2}$, medium was replaced by the products in Table $\mathbf{1}$ in SECSM. Following an additional 20 -h incubation at $37^{\circ} \mathrm{C}$ and $5 \% \mathrm{CO}_{2}$, plates were developed as described by Kieckens et al. (26), with some minor adjustments. Briefly, $20 \mu \mathrm{L}$ of $5 \mathrm{mg} / \mathrm{mL}$ MTT [3-(4,5-dimethyl-2-thiazolyl)2,5-diphenyl-2H-tetrazolium bromide] in Hanks balanced salt solution (Thermo Fisher Scientific) was added to each well, followed by 4 -h incubation $\left(37^{\circ} \mathrm{C}, 5 \% \mathrm{CO}_{2}\right)$. After removal of the supernatant, the formed formazan crystals were dissolved in 1:1 (vol/vol) ethanol/dimethyl sulfoxide using gentle resuspension, followed by measurement of the optical density (OD) at $560 \mathrm{~nm}$ (OD1) and $620 \mathrm{~nm}(\mathrm{OD} 2)$. OD2 was subtracted from OD1, and results were finally expressed as the percentage viable cells by dividing OD values of the stimulated wells by those of the unstimulated control.

\section{Cytokine Enzyme-Linked Immunosorbent Assays}

The secretion of the proinflammatory cytokine IL- 6 , the chemokine IL-8/CXCL8, and the anti-inflammatory cytokine 
IL-10 in cell-free supernatants was measured using caninespecific DuoSet enzyme-linked immunosorbent assay (ELISA) kits (R\&D Systems, Minneapolis, MN, USA) according to the manufacturer's instructions. Human and canine transforming growth factor $\beta 1$ (TGF- $\beta 1$ ) were shown to have high homology (27), and therefore, the human TGF- $\beta 1$ ELISA was used to detect canine TGF- $\beta 1$ (28).

\section{RNA Extraction and RNA-Sequencing}

RNA extraction and DNase treatment of the samples was performed using the RNeasy mini kit and Rnase-Free DNase Set (Qiagen) according to the manufacturer's instructions. Extracted RNA was stored at $-80^{\circ} \mathrm{C}$. Total RNA concentration was measured using the Quant-iT RiboGreen RNA Assay Kit (Thermo Fisher Scientific). RNA quality was inspected using an RNA 6000 Nano chip on a BioAnalyser (Agilent Technologies, Santa Clara, CA, USA). For each sample, a sequencing library was constructed using the QuantSeq 3' mRNA-Seq Library Prep Kit FWD for Illumina (Lexogen, Vienna, Austria) starting from $500 \mathrm{ng}$ total RNA and amplified by 14 polymerase chain reaction (PCR) cycles. Quality and size distribution of the libraries were checked on a BioAnalyser (Agilent Technologies) using the highsensitivity Quant-iT dsDNA Assay Kit (Thermo Fisher Scientific) and a high-sensitivity DNA chip. Library concentration was determined according to Illumina's Sequencing Library qPCR Quantification Guide on a LightCycler 480 (Roche Life Science, Penzberg, Germany). Sequencing of the libraries was done at Ghent University's NxtGnt sequencing facility as single-read 75 bp on a NextSeq 500 sequencer (Illumina, San Diego, CA, USA) using four lanes per sample. Subsequently, sequencing read quantity and quality were checked using FastQC (v0.11.8). Contamination was determined using FastQ Screen (v0.14.0). Adapter trimming and removal of reads having a quality score lower than 20 or containing any ambiguities were done using cutadapt (v2.5). The remaining high-quality reads were mapped on the CanFam3.1 reference dog genome using STAR (v2.7.2), and features were count at the gene level using RSEM (v1.3.1).

\section{Statistical Analysis}

Statistical analysis was performed using R [R Core Team (29)]. Normal distribution of the data was assessed using the ShapiroWilk test and quantile-quantile plot. Log-transformed ELISA concentrations and untransformed data of the MTT test were normally distributed and analyzed using the paired Student $t$-test. A $p<0.05$ was considered statistically significant. Differential expression analyses of the RNA-sequencing data were done in $\mathrm{R}$ using the edgeR (v3.26.8) package. For each analysis, feature counts were normalized using edgeR's standard normalization method. To remove uninformative low-count features, those having $<1 \mathrm{cpm}$ (counts per million) in the number of samples equivalent to the size of the smallest group were discarded. Statistical testing was done by fitting a general linear model, followed by a quasi-likelihood F test. Differentially expressed features were considered statistically significant when having a fold change of at least 2 (doubling or halving between the compared groups) and a false discovery rate (or adjusted $p$-value according to Benjamini-Hochberg) smaller than or equal to 0.05 .

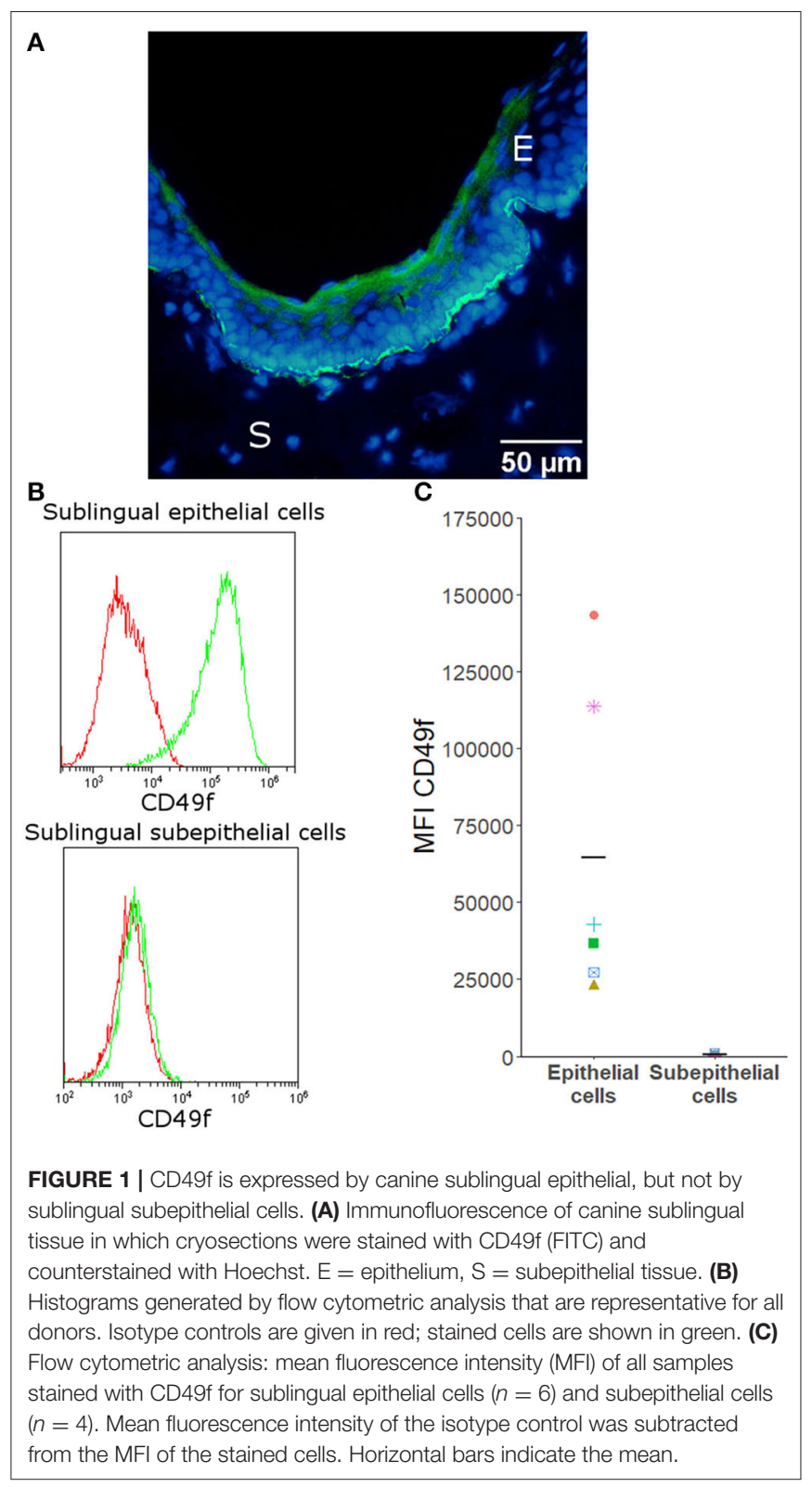

\section{RESULTS}

\section{A D. farinae Extract and TLR Ligands Increase CXCL8 Secretion While Calcitriol Suppresses It}

To assess whether two house dust mite extracts might modulate cytokine secretion by canine primary sublingual epithelial cells, cells were isolated from sublingual biopsies. Immunofluorescence staining and flow cytometry showed that the isolated sublingual cells stained positive for the epithelial marker CD49f (Figure 1).

Next, it was evaluated whether an allergen extract of $D$. farinae and D. pteronyssinus could alter the sublingual epithelial cells' cytokine secretion. The $D$. farinae extract induced a significant 
increase in CXCL8 secretion as compared to the unstimulated controls and D. pteronyssinus extract (Figure 2). Therefore, we used this $D$. farinae extract to evaluate the effect of potential adjuvants on the CXCL8 response.

Different potential adjuvants were tested for their direct effect on cytokine secretion by canine sublingual epithelial cells. The TLR2 ligands, FSL-1, HKLM, and Pam3CSK4, and TLR3 ligands, poly I:C high (HMW) and low molecular weight (LMW), significantly increased CXCL8 secretion by sublingual epithelial cells ( $p<0.05$; Figure 3). Calcitriol was able to significantly suppress the CXCL8 secretion at concentrations of 1 and $0.1 \mu \mathrm{M}$ $(p<0.05$ ), but not at $0.01 \mu \mathrm{M}$ (Figure 4). The sublingual epithelial cells constitutively produced TGF- $\beta 1$ (unstimulated control: $41 \pm 15 \mathrm{pg} / \mathrm{mL}$; median \pm interquartile range), and this did not change significantly when incubated with the $D$. farinae extract, TLR ligands, or calcitriol (data not shown). Neither unstimulated nor stimulated sublingual epithelial cells detectably produced the proinflammatory cytokine IL-6 or the anti-inflammatory cytokine IL-10.

Neither $D$. farinae extract at $20 \mu \mathrm{g} / \mathrm{mL}$, nor the TLR ligands FSL- 1 at $1 \mu \mathrm{g} / \mathrm{mL}$, HKLM at $10^{8}$ cells $/ \mathrm{mL}$, Pam3CSK 4 at $1 \mu \mathrm{g} / \mathrm{mL}$, lipopolysaccharide (LPS) at $10 \mu \mathrm{g} / \mathrm{mL}$, or calcitriol at $0.1 \mu \mathrm{M}$ had a significant effect on cell viability after 24$\mathrm{h}$ incubation. Only poly I:C HMW $(57 \% \pm 12 \%$; mean \pm standard deviation) and LMW (73\% $\pm 5 \%)$ significantly decreased the viability of canine sublingual epithelial cells $(p<0.001)$ (Figure 5).

\section{Calcitriol Can Suppress CXCL8 Secretion by Canine Sublingual Epithelial Cells Even in the Presence of $D$. farinae}

To investigate the effects of calcitriol on canine sublingual epithelial cells when coadministered with the extract of $D$. farinae, cells were incubated with $D$. farinae extract alone, a combination of $D$. farinae extract with calcitriol, or with medium without stimulus. Costimulation with calcitriol and $D$. farinae significantly suppressed CXCL8 production as compared to cells stimulated with $D$. farinae alone $(p<0.05)$. There was no significant difference in CXCL8 secretion between cells stimulated with D. farinae and calcitriol combined and cells cultured without any stimulus, suggesting maintenance of normal CXCL8 secretion levels (Figure 6).

\section{Calcitriol Induces Glucocorticoid Receptor and Prostaglandin E Synthase mRNA Expression}

No significantly differentially expressed genes could be identified when comparing RNA-sequencing data of sublingual epithelial cells incubated with and without D. farinae extract. Calcitriol, however, did significantly upregulate 13 genes compared to unstimulated cells, among which NR3C1, the glucocorticoid receptor; CYP24A1, a cytochrome P450 that catabolizes vitamin D; and PTGES, an enzyme that generates prostaglandin E (Table 2). Interestingly, in all the conditions tested, transcript counts of less than 1 count per million were observed for IL- $1 \alpha$, IL-1 $\beta$, IL-6, IL-10, IL-25, IL-33, and TSLP.

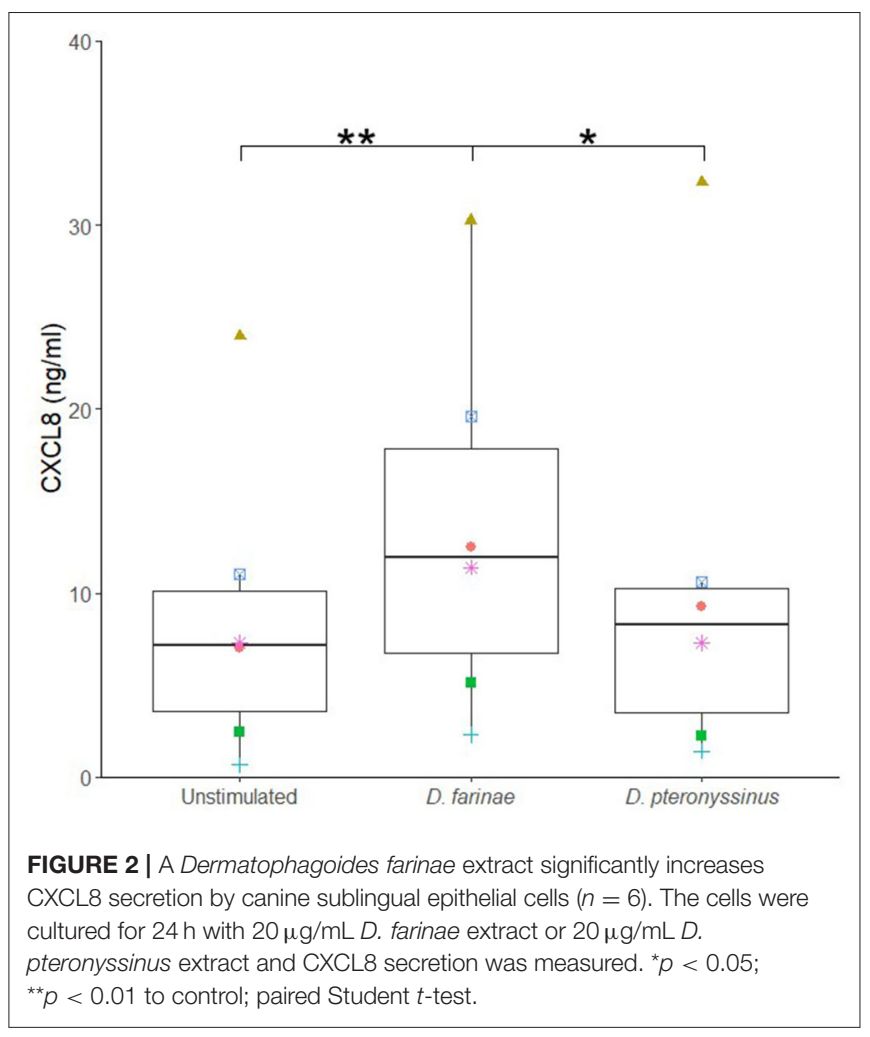

\section{DISCUSSION}

In this study, primary sublingual epithelial cells from dogs were isolated from biopsies, cultured in vitro, and characterized for expression of the marker CD49f. All sublingual epithelial cells stained positive for this marker. This is in agreement with findings in humans and dogs, which showed that CD49f is a reliable marker to identify epithelial cells (30-33).

Canine sublingual epithelial cells were stimulated with a D. farinae extract, a D. pteronyssinus extract, different TLR ligands, and calcitriol to assess differences in their cytokine and chemokine secretion profile. Only the production of CXCL8 could be significantly modulated. This proinflammatory chemokine is capable of attracting neutrophils and $\mathrm{T}$ lymphocytes $(34,35)$. The oral cavity contains low numbers of proinflammatory effector cells $(36,37)$, and the absence of proinflammatory signals likely explains the facilitated generation of antigen-specific tolerance. During SLIT, allergens are administered onto sublingual epithelial cells. These cells showed a significant increase in CXCL8 secretion when stimulated with a $D$. farinae extract. Also, in human and canine epidermal keratinocytes, crude extracts of $D$. farinae and its allergenic protein, Der f 1 , increased the expression of proallergenic mediators and proinflammatory cytokines $(11,38)$. It should be noted that, in both cited studies, the allergen exposure protocol was insufficiently documented, and that in the study of Maeda et al. (38), the activation state and purity of the Der $\mathrm{f} 1$ were not assessed. It should also be mentioned that, in order to generate more representative results for the sublingual epithelial cells, a 
mimic of the mucosal lining fluid and saliva could have been used rather than serum-free medium. While another study showed that $D$. pteronyssinus proteins can induce proinflammatory cytokine expression in epithelial cells (8), the D. pteronyssinus extract we used did not modulate cytokine secretion by the sublingual epithelial cells. Differences in composition of the mite extracts could explain this discrepancy in response (39). Nonetheless, the D. farinae extract did induce CXCL8 secretion by canine sublingual epithelial cells, which indicates that application of such an extract onto the sublingual epithelium has the potential to generate a proinflammatory response in the oral mucosa.

When the effect of different TLR ligands was investigated, the TLR2 ligands Pam3CSK4, HKLM, and FSL-1, and the TLR3 ligand, poly I:C, but not LPS, significantly stimulated CXCL8 secretion. In the past, TLR2 ligands were shown to be promising adjuvants for allergy treatment in some studies (16-18), whereas other studies with mouse asthma models showed that TLR2 ligands could enhance proallergenic responses $(40,41)$. In canine epidermal keratinocytes, LPS and Pam3CSK4 also promoted the secretion of proinflammatory and proallergenic mediators (4244). Additionally, the TLR3 ligand, poly I:C, had a significant lethal effect on the sublingual epithelial cells, as was observed for bronchial epithelial cells as well as in epidermal keratinocytes (45, 46). The use of TLR ligands during SLIT is therefore likely to have a negative impact on the tolerance-promoting anti-inflammatory environment of the oral mucosa.

Calcitriol or 1,25-dihydroxyvitamin $\mathrm{D}_{3}$ is a small lipophilic molecule that easily penetrates cell membranes through diffusion $(22,47)$, after which it can bind to the vitamin D receptor of epithelial cells and regulate several genes (48). Interestingly, in combination with the $D$. farinae extract, calcitriol significantly reduced CXCL8 secretion by canine sublingual epithelial cells. During SLIT, calcitriol therefore seems promising to prevent an allergen extract-induced increase in

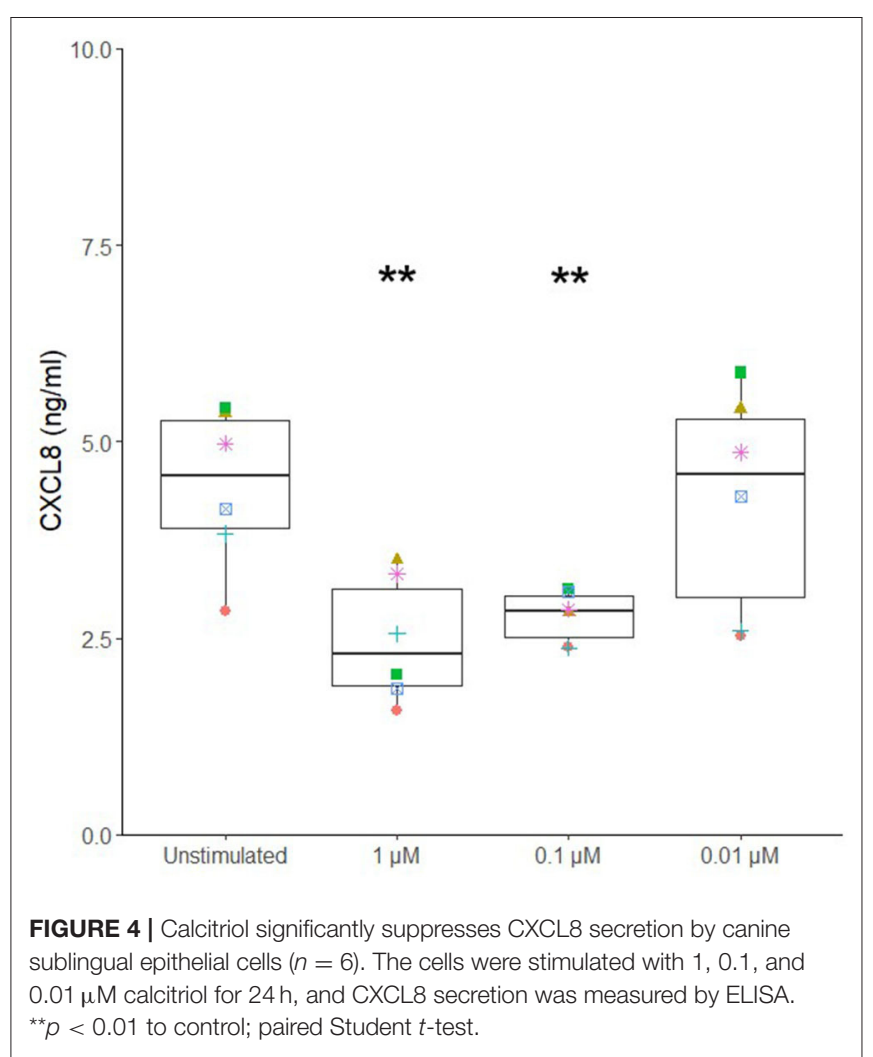

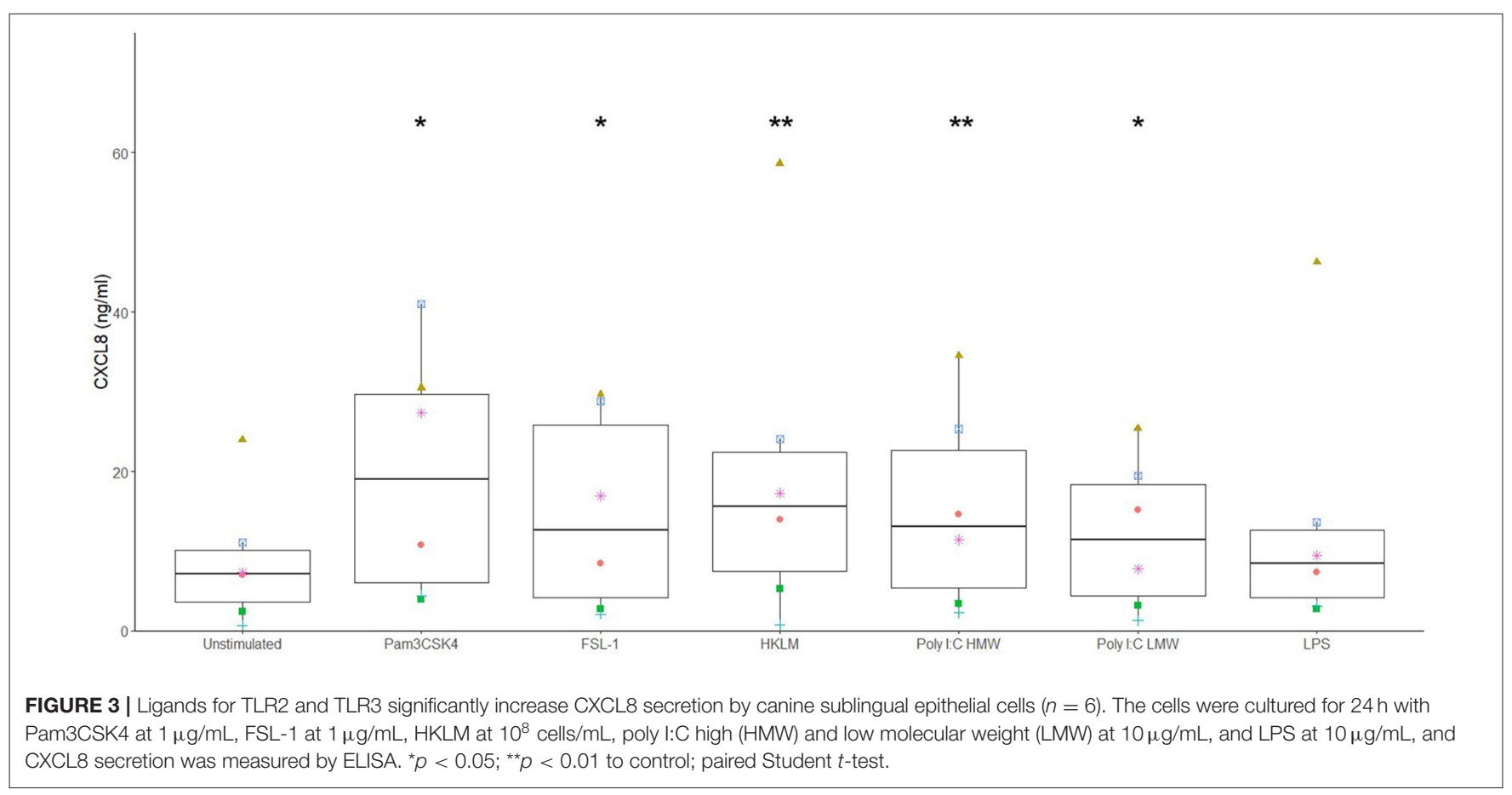




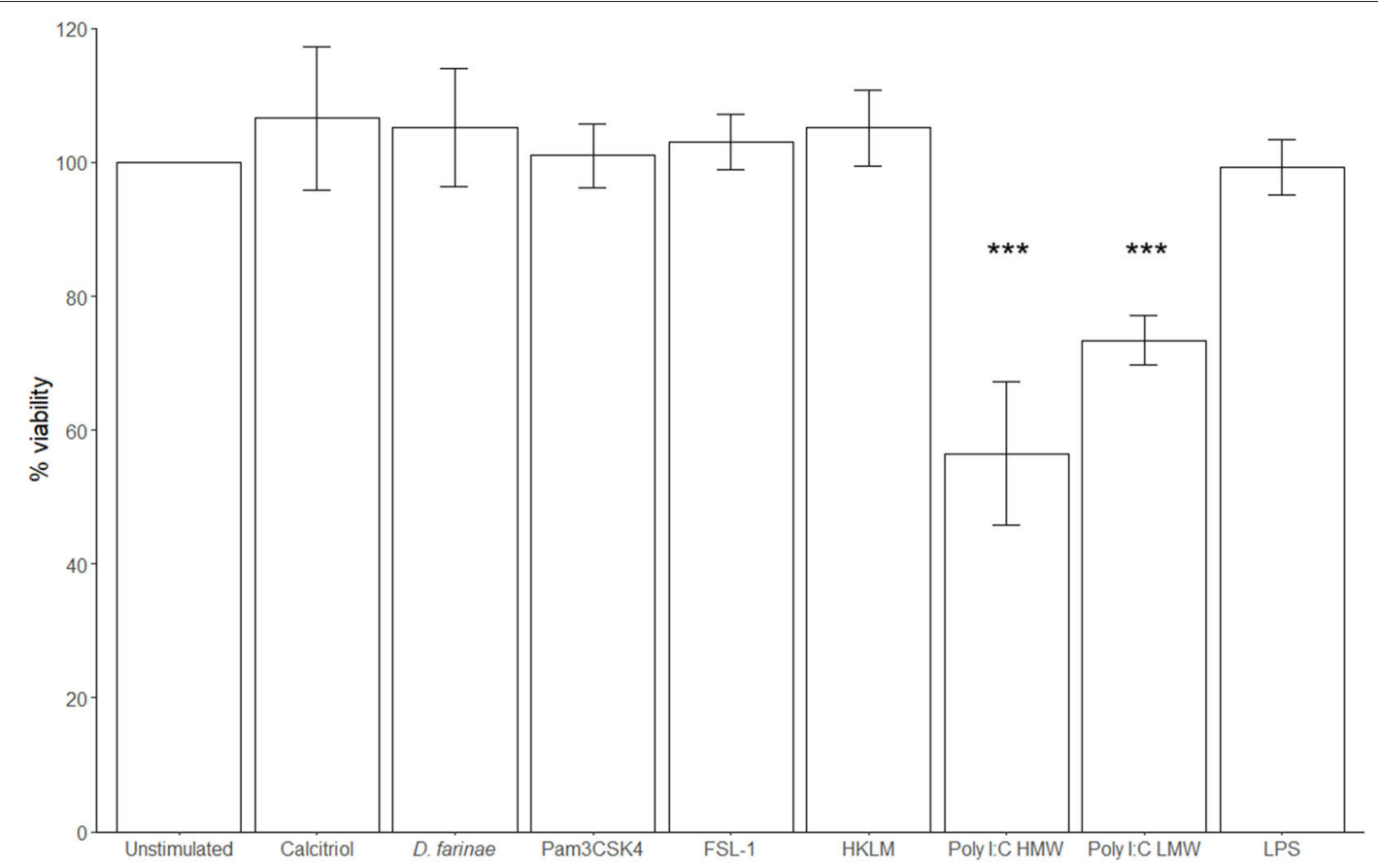

FIGURE 5 | The TLR3 ligand poly I:C significantly decreases the viability of canine sublingual epithelial cells $(n=6)$. The cells were cultured for $24 \mathrm{~h}$ with $0.1 \mu \mathrm{M}$ calcitriol, D. farinae extract at $20 \mu \mathrm{g} / \mathrm{mL}$, Pam3CSK4 at $1 \mu \mathrm{g} / \mathrm{mL}$, FSL-1 at $1 \mu \mathrm{g} / \mathrm{mL}$, HKLM at $10^{8} \mathrm{cells} / \mathrm{mL}$, poly l:C high (HMW) and low molecular weight (LMW) at $10 \mu \mathrm{g} / \mathrm{mL}$, and LPS at $10 \mu \mathrm{g} / \mathrm{mL}$, and the effect on cell viability was assessed using an MTT test. ${ }^{* \star \star} p<0.001$ to control; paired Student $t$-test. Error bars: standard deviation.

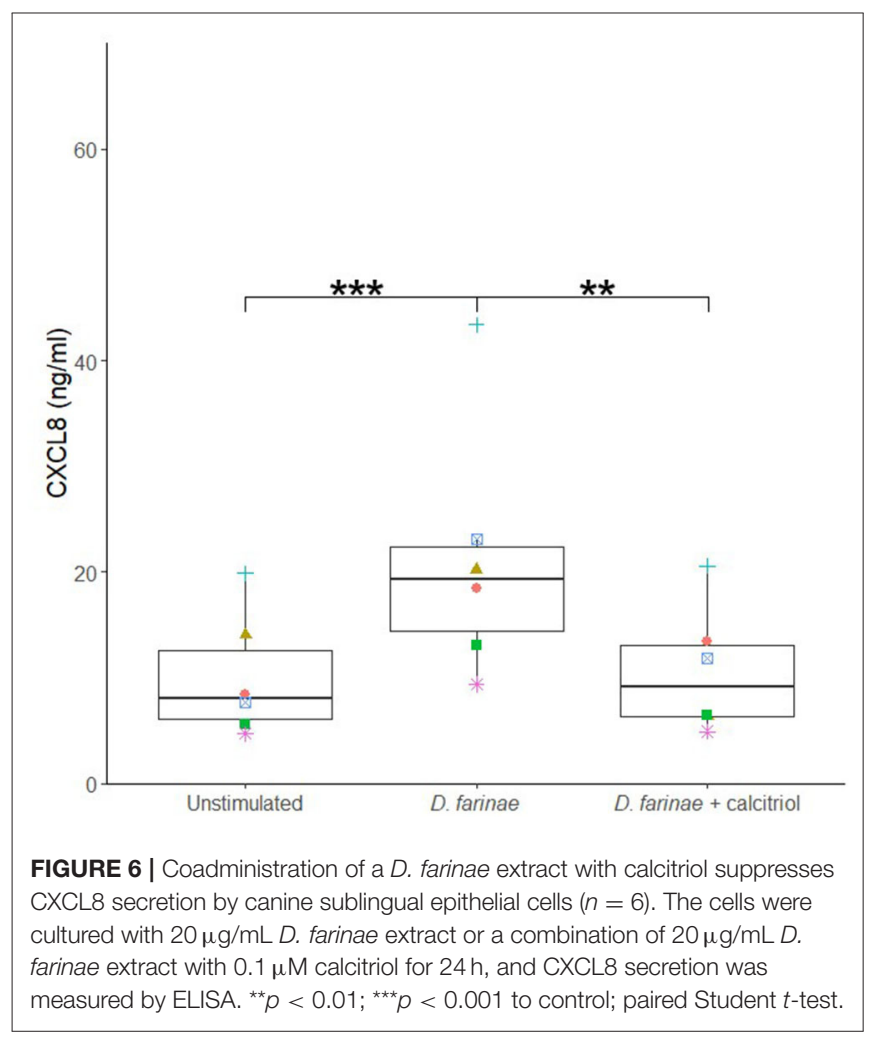

TABLE 2 | Calcitriol-induced gene expression in canine sublingual epithelial cells $(n=5)$. Cells were incubated with $0.1 \mu \mathrm{M}$ calcitriol for $6 \mathrm{~h}$.

\begin{tabular}{lcc}
\hline Gene & Fold change & Adjusted $\boldsymbol{p}$-value \\
\hline NR3C1 & 2.21 & 0.004 \\
CYP24A1 & 500 & 0.008 \\
C28H10orf90 & 5.65 & 0.008 \\
PTGES & 1.95 & 0.012 \\
KALRN & 1.59 & 0.013 \\
HMOX1 & 3.82 & 0.022 \\
OSGIN1 & 22.22 & 0.022 \\
SLC4A7 & 2.23 & 0.027 \\
SEMA4D & 3.24 & 0.029 \\
KIF26A & 1.95 & 0.037 \\
KCNK10 & 14.08 & 0.038 \\
LMCD1 & 2.26 & 0.044 \\
TMC7 & 1.94 & 0.045 \\
\hline
\end{tabular}

Fold changes to the unstimulated control are given.

CXCL8 secretion by sublingual epithelial cells. Interestingly, calcitriol significantly upregulated the mRNA expression of $\mathrm{NR} 3 \mathrm{C} 1$, the receptor for glucocorticoids. Indeed, calcitriol and the glucocorticoid dexamethasone were shown to have a combined tolerance-promoting effect when sublingually 
administered in a mouse model (21). Additionally, augmented expression of the prostaglandin E-generating enzyme PTGES was observed. Prostaglandin E has both proinflammatory and anti-inflammatory properties, being capable of activating mast cells (49), whereas secretion by bronchial epithelial cells has an anti-inflammatory effect on murine dendritic cells (50). Calcitriol can have an ambiguous effect on the proliferation of human epithelial cells, with low concentrations $\left(10^{-9}-10^{-11} \mathrm{M}\right)$ promoting the proliferation of human epidermal keratinocytes, whereas higher concentrations $\left(>10^{-8} \mathrm{M}\right)$ inhibited keratinocyte proliferation in vitro $(51,52)$. However, in our hands, calcitriol did not affect the viability and metabolic activity of canine sublingual epithelial cells, as was shown for human bronchial epithelial cells (53). Nevertheless, if calcitriol would be used as an adjuvant during SLIT, the effects of repeated administration on the oral mucosa should be investigated.

Although low concentrations of TGF- $\beta 1$ could be detected in canine sublingual epithelial cell supernatant, neither calcitriol nor the TLR ligands or the $D$. farinae extract significantly changed the secretion of this cytokine. In humans, calcitriol was shown to induce TGF- $\beta$ in epidermal keratinocytes (48), whereas incubation of primary oral epithelial cells with bacteria suppressed the secretion of this cytokine (54). In the context of allergies, TGF- $\beta$ generally leads to allergen-tolerating responses by inducing regulatory $\mathrm{T}$ cells and promoting an isotype shift in $\mathrm{B}$ cells in favor of IgA production $(55,56)$. Substances that increase TGF- $\beta$ secretion by sublingual epithelial cells would therefore be interesting candidates for use as adjuvants during SLIT. While production of IL- 6 and IL-10 has been observed in other types of epithelial cells (57-63), no secretion of these cytokines was detected for canine sublingual epithelial cells by ELISA or RNA sequencing. Furthermore, proallergenic mediators associated with the epithelium, TSLP, IL-25, and IL-33 $(4,64)$ and the proinflammatory cytokines IL- $1 \alpha$ and IL- $1 \beta$ were not expressed by canine sublingual epithelial cells. Whether this difference in mediator expression compared to epithelial cells of other tissues is due to specific properties of the canine sublingual epithelium should be investigated.

In this study, canine sublingual epithelial cells were cultured as a monolayer. However, the sublingual epithelium consists of 12-18 layers in dogs (65). This difference might limit the conclusions that can be drawn for in vivo applications. Indeed, cytokine secretion repertoires of epidermal keratinocytes differed when cultured as a monolayer compared to a more complex multilayered culture model (39). Nevertheless, unlike the skin, the canine sublingual epithelium is non-keratinized tissue, which allows penetration of molecules to the level of the basal epithelial cells to exert their effects $(37,65)$. This study therefore provides relevant insights into which mediators can be produced by sublingual epithelial cells positioned close to the basement membrane, mediators that could influence the behavior of local immune cells.

In conclusion, canine primary sublingual epithelial cells were isolated from dogs and showed increased secretion of CXCL8 in response to a $D$. farinae extract, TLR2, and TLR3 ligands, whereas the production of this chemokine could be suppressed by calcitriol. Furthermore, when applied onto the cells together with an extract of D. farinae, calcitriol downregulated CXCL8 concentrations to levels similar to those observed in unstimulated sublingual epithelial cells. As such, calcitriol seems to be a promising adjuvant for use during SLIT because it might help to maintain the tolerance-inducing properties of the oral mucosa during desensitizing treatments.

\section{DATA AVAILABILITY STATEMENT}

All datasets generated for this study are included in the article/ Supplementary Material. The RNA-sequencing data discussed in this publication have been deposited in NCBI's Gene Expression Omnibus (66) and are accessible through GEO Series accession number GSE148592 (https://www.ncbi.nlm.nih.gov/ geo/query/acc.cgi? acc=GSE148592).

\section{ETHICS STATEMENT}

Ethical review and approval was not required for the animal study because the samples were collected from corpses of animals that were euthanised for reasons independent of this study. Oral informed consent was given by all owners.

\section{AUTHOR CONTRIBUTIONS}

EC conceptualized the study. MP, $\mathrm{CH}$, and $\mathrm{CW}$ performed the experiments, acquired, and analyzed the data. MP drafted the manuscript. $\mathrm{BD}, \mathrm{HD}$, and $\mathrm{EC}$ gave valuable input on the revision of the manuscript. FV contributed to the design of the RNA-sequencing experiment. YG and FV performed the statistical analysis on the RNA-sequencing data. All authors contributed to manuscript revision, read, and approved the submitted version.

\section{FUNDING}

This study was funded by a $\mathrm{PhD}$ Fellowship of the Research Foundation - Flanders (FWO - 1S23718N). BD is supported by a postdoctoral grant of the Research Foundation - Flanders.

\section{ACKNOWLEDGMENTS}

MP would like to show his gratitude to the surgery team of the Ghent University's small animal department and to the 2018-2019 small animal rotating interns for their help with the recruitment of the corpses for the collection of the biopsies.

\section{SUPPLEMENTARY MATERIAL}

The Supplementary Material for this article can be found online at: https://www.frontiersin.org/articles/10.3389/fimmu. 2020.01033/full\#supplementary-material 


\section{REFERENCES}

1. Jutel M, Akdis CA. Immunological mechanisms of allergen-specific immunotherapy: immunological mechanisms of allergen-specific immunotherapy. Allergy. (2011) 66:725-32. doi: 10.1111/j.1398-9995. 2011.02589.x

2. Wilson DR, Torres LI, Durham SR. Sublingual immunotherapy for allergic rhinitis. Cochrane Database Syst Rev. (2003) CD002893. doi: 10.1002/14651858.CD002893

3. Maina E, Cox E. A double blind, randomized, placebo controlled trial of the efficacy, quality of life and safety of food allergen-specific sublingual immunotherapy in client owned dogs with adverse food reactions: a small pilot study. Vet Dermatol. (2016) 27:361-e91. doi: 10.1111/vde.12358

4. Divekar R, Kita H. Recent advances in epithelium-derived cytokines (IL-33, IL-25, and thymic stromal lymphopoietin) and allergic inflammation. Curr Opin Allergy Clin Immunol. (2015) 15:98-103. doi: 10.1097/ACI.0000000000000133

5. Soumelis V, Reche PA, Kanzler H, Yuan W, Edward G, Homey B, et al. Human epithelial cells trigger dendritic cell-mediated allergic inflammation by producing TSLP. Nat Immunol. (2002) 3:673-80. doi: 10.1038/ni805

6. Calderón MA, Kleine-Tebbe J, Linneberg A, de Blay F, Hernandez Fernandez de Rojas D, Virchow JC, et al. House dust mite respiratory allergy: an overview of current therapeutic strategies. J Allergy Clin Immunol Pract. (2015) 3:84355. doi: 10.1016/j.jaip.2015.06.019

7. Hill PB, deBoer DJ. The ACVD task force on canine atopic dermatitis (IV): environmental allergens. Vet Immunol Immunopathol. (2001) 81:169-86. doi: 10.1016/S0165-2427(01)00298-7

8. Asokananthan N, Graham PT, Stewart DJ, Bakker AJ, Eidne KA, Thompson PJ, et al. House dust mite allergens induce proinflammatory cytokines from respiratory epithelial cells: the cysteine protease allergen, der $\mathrm{p} 1$, activates protease-activated receptor (PAR)-2 and inactivates PAR-1. J Immunol. (2002) 169:4572-8. doi: 10.4049/jimmunol.169.8.4572

9. Choi H-J, Park S-Y, Cho JH, Park J-W, Sohn J-H, Kim Y-J, et al. The TLR4associated phospholipase D1 activation is crucial for Der f 2-induced IL-13 production. Allergy. (2015) 70:1569-79. doi: 10.1111/all.12764

10. Satitsuksanoa P, Kennedy M, Gilis D, Le Mignon M, Suratannon N, Soh WT, et al. The minor house dust mite allergen Der p 13 is a fatty acid-binding protein and an activator of a TLR2-mediated innate immune response. Allergy. (2016) 71:1425-34. doi: 10.1111/all.12899

11. Jang YH, Choi JK, Jin M, Choi Y-A, Ryoo ZY, Lee H-S, et al. House dust mite increases pro-Th2 cytokines IL-25 and IL-33 via the activation of TLR1/6 signaling. J Invest Dermatol. (2017) 137:2354-61. doi: 10.1016/j.jid.2017.03.042

12. Hammad H, Chieppa M, Perros F, Willart MA, Germain RN, Lambrecht BN. House dust mite allergen induces asthma via Toll-like receptor 4 triggering of airway structural cells. Nat Med. (2009) 15:410-6. doi: 10.1038/nm.1946

13. Trompette A, Divanovic S, Visintin A, Blanchard C, Hegde RS, Madan R, et al. Allergenicity resulting from functional mimicry of a Toll-like receptor complex protein. Nature. (2009) 457:585-8. doi: 10.1038/nature07548

14. Willart MAM, Deswarte K, Pouliot P, Braun H, Beyaert R, Lambrecht BN, et al. Interleukin- $1 \alpha$ controls allergic sensitization to inhaled house dust mite via the epithelial release of GM-CSF and IL-33. J Exp Med. (2012) 209:1505-17. doi: 10.1084/jem.20112691

15. Moingeon $\mathrm{P}$, Mascarell L. Induction of tolerance via the sublingual route: mechanisms and applications. Clin Dev Immunol. (2012) 2012:623474. doi: 10.1155/2012/623474

16. Lombardi V, Van Overtvelt L, Horiot S, Moussu H, Chabre H, Louise A, et al. Toll-like receptor 2 agonist Pam3CSK4 enhances the induction of antigen-specific tolerance via the sublingual route. Clin Exp Allergy. (2008) 38:1819-29. doi: 10.1111/j.1365-2222.2008.03056.x

17. Akdis CA, Kussebi F, Pulendran B, Akdis M, Lauener RP, Schmidt-Weber $\mathrm{CB}$, et al. Inhibition of $\mathrm{T}$ helper 2-type responses, $\operatorname{IgE}$ production and eosinophilia by synthetic lipopeptides. Eur J Immunol. (2003) 33:2717-26. doi: 10.1002/eji.200323329

18. Taylor RC, Richmond P, Upham JW. Toll-like receptor 2 ligands inhibit TH2 responses to mite allergen. J Allergy Clin Immunol. (2006) 117:1148-54. doi: 10.1016/j.jaci.2006.02.014
19. Mothes N, Heinzkill M, Drachenberg KJ, Sperr WR, Krauth MT, Majlesi $\mathrm{Y}$, et al. Allergen-specific immunotherapy with a monophosphoryl lipid A-adjuvanted vaccine: reduced seasonally boosted immunoglobulin E production and inhibition of basophil histamine release by therapy-induced blocking antibodies. Clin Htmlent Glyphamp Asciiamp Exp Allergy. (2003) 33:1198-208. doi: 10.1046/j.1365-2222.2003.01699.x

20. Pedersen AE, Gad M, Walter MR, Claesson MH. Induction of regulatory dendritic cells by dexamethasone and 1 $\alpha, 25$-Dihydroxyvitamin D3. Immunol Lett. (2004) 91:63-9. doi: 10.1016/j.imlet.2003.11.004

21. van Overtvelt L, Lombardi V, Razafindratsita A, Saint-Lu N, Horiot S, Moussu $\mathrm{H}$, et al. IL-10-inducing adjuvants enhance sublingual immunotherapy efficacy in a murine asthma model. Int Arch Allergy Immunol. (2008) 145:15262. doi: 10.1159/000108140

22. Kang SW, Kim SH, Lee N, Lee W-W, Hwang K-A, Shin MS, et al. 1,25Dihyroxyvitamin $\mathrm{D}_{3}$ promotes FOXP3 expression via binding to vitamin D response elements in its conserved noncoding sequence region. J Immunol. (2012) 188:5276-82. doi: 10.4049/jimmunol.1101211

23. Murakami D, Yamato M, Nishida K, Ohki T, Takagi R, Yang J, et al. Fabrication of transplantable human oral mucosal epithelial cell sheets using temperatureresponsive culture inserts without feeder layer cells. J Artif Organs. (2006) 9:185-91. doi: 10.1007/s10047-006-0342-3

24. Kondo M, Yamato M, Takagi R, Murakami D, Namiki H, Okano T. Significantly different proliferative potential of oral mucosal epithelial cells between six animal species: proliferative potential comparison of oral mucosal epithelial cells among six species. J Biomed Mater Res A. (2014) 102:1829-37. doi: 10.1002/jbm.a.34849

25. Schneider CA, Rasband WS, Eliceiri KW. NIH image to imageJ: 25 years of image analysis. Nat Methods. (2012) 9:671-5. doi: 10.1038/nmeth.2089

26. Kieckens E, Rybarczyk J, Barth SA, Menge C, Cox E, Vanrompay D. Effect of lactoferrin on release and bioactivity of Shiga toxins from different Escherichia coli O157:H7 strains. Vet Microbiol. (2017) 202:29-37. doi: 10.1016/j.vetmic.2016.03.013

27. Manning AM, Auchampach JA, Drong RF, Slightom JL. Cloning of a canine cDNA homologous to the human transforming growth factor- $\beta 1$-encoding gene. Gene. (1995) 155:307-8. doi: 10.1016/0378-1119(94)00903-6

28. Corrêa APFL, Dossi ACS, de Oliveira Vasconcelos R, Munari DP, de Lima VMF. Evaluation of transformation growth factor $\beta 1$, interleukin-10, and interferon- $\gamma$ in male symptomatic and asymptomatic dogs naturally infected by Leishmania (Leishmania) chagasi. Vet Parasitol. (2007) 143:26774. doi: 10.1016/j.vetpar.2006.08.023

29. R Core Team. R: A Language and Environment for Statistical Computing. Vienna: R Foundation for Statistical Computing (2019). Available online at: http://www.R-project.org/

30. Li A, Simmons PJ, Kaur P. Identification and isolation of candidate human keratinocyte stem cells based on cell surface phenotype. Proc Natl Acad Sci USA. (1998) 95:3902-7. doi: 10.1073/pnas.95.7.3902

31. Calenic B, Ishkitiev N, Yaegaki K, Imai T, Kumazawa Y, Nasu M, et al. Magnetic separation and characterization of keratinocyte stem cells from human gingiva: magnetic separation of oral keratinocyte stem cells. J Periodontal Res. (2010) 45:703-8. doi: 10.1111/j.1600-0765.2010.01284.x

32. Yamazoe K, Miyamoto S, Hikosaka Y, Kitagawa K, Watanabe K, Sakai H, et al. Three-Dimensional culture of keratinocytes and the formation of basement membrane for canine footpad substitute. J Vet Med Sci. (2007) 69:611-7. doi: 10.1292/jvms.69.611

33. Shibata S, Maeda S, Tsuchida H, Fukata T. Phenotypic analysis for a cell line of canine epidermal keratinocytes. J Vet Med Sci. (2008) 70:853-5. doi: 10.1292/jvms.70.853

34. Russo RC, Garcia CC, Teixeira MM, Amaral FA. The CXCL8/IL-8 chemokine family and its receptors in inflammatory diseases. Expert Rev Clin Immunol. (2014) 10:593-619. doi: 10.1586/1744666X.2014.894886

35. Barker JN, Jones ML, Mitra RS, Crockett-Torabe E, Fantone JC, Kunkel SL, et al. Modulation of keratinocyte-derived interleukin- 8 which is chemotactic for neutrophils and T lymphocytes. Am J Pathol. (1991) 139:869-76.

36. Allam J-P, Stojanovski G, Friedrichs N, Peng W, Bieber T, Wenzel J, et al. Distribution of Langerhans cells and mast cells within the human oral mucosa: new application sites of allergens in sublingual immunotherapy? Allergy. (2008) 63:720-7. doi: 10.1111/j.1398-9995.2007.01611.x 
37. Mascarell L, Lombardi V, Louise A, Saint-Lu N, Chabre H, Moussu H, et al. Oral dendritic cells mediate antigen-specific tolerance by stimulating TH1 and regulatory CD4+ T cells. J Allergy Clin Immunol. (2008) 122:603-9.e5. doi: 10.1016/j.jaci.2008.06.034

38. Maeda S, Maeda S, Shibata S, Chimura N, Fukata T. House dust mite major allergen Der f 1 enhances proinflammatory cytokine and chemokine gene expression in a cell line of canine epidermal keratinocytes. Vet Immunol Immunopathol. (2009) 131:298-302. doi: 10.1016/j.vetimm.2009.04.012

39. Arlian LG, Morgan MS. Immunomodulation of skin cytokine secretion by house dust mite extracts. Int Arch Allergy Immunol. (2011) 156:171-8. doi: 10.1159/000323351

40. Chisholm D, Libet L, Hayashi T, Horner AA. Airway peptidoglycan and immunostimulatory DNA exposures have divergent effects on the development of airway allergen hypersensitivities. J Allergy Clin Immunol. (2004) 113:448-54. doi: 10.1016/j.jaci.2003.12.011

41. Redecke V, Häcker H, Datta SK, Fermin A, Pitha PM, Broide DH, et al. Cutting edge: activation of toll-like receptor 2 induces a Th2 immune response and promotes experimental asthma. J Immunol. (2004) 172:2739-43. doi: 10.4049/jimmunol.172.5.2739

42. Ibisch C, Bourdeau P, Cadiot C, Viac J, Gatto H. Upregulation of TNF- $\alpha$ production by IFN- $\gamma$ and LPS in cultured canine keratinocytes: application to monosaccharides effects. Vet Res Commun. (2007) 31:835-46. doi: 10.1007/s11259-007-0004-9

43. Sakamoto M, Asahina R, Kamishina H, Maeda S. Transcription of thymic stromal lymphopoietin via Toll-like receptor 2 in canine keratinocytes: a possible association of Staphylococcus spp in the deterioration of allergic inflammation in canine atopic dermatitis. Vet Dermatol. (2016) 27:184-e46. doi: 10.1111/vde.12301

44. Chermprapai S, Broere F, Schlotter YM, Veldhuizen EJA, Rutten VPMG. A canine keratinocyte cell line expresses antimicrobial peptide and cytokine genes upon stimulation with bacteria, microbial ligands and recombinant cytokines. Vet Immunol Immunopathol. (2018) 206:35-40. doi: 10.1016/j.vetimm.2018.11.009

45. Lian L-H, Milora KA, Manupipatpong KK, Jensen LE. The doublestranded RNA analogue polyinosinic-polycytidylic acid induces keratinocyte pyroptosis and release of IL-36 $\gamma$. J Invest Dermatol. (2012) 132:1346-53. doi: $10.1038 /$ jid.2011.482

46. Koizumi Y, Nagase H, Nakajima T, Kawamura M, Ohta K. Toll-like receptor 3 ligand specifically induced bronchial epithelial cell death in caspase dependent manner and functionally upregulated Fas expression. Allergol Int. (2016) 65:S30-7. doi: 10.1016/j.alit.2016.05.006

47. Mora JR, Iwata M, von Andrian UH. Vitamin effects on the immune system: vitamins A and D take centre stage. Nat Rev Immunol. (2008) 8:685-98. doi: $10.1038 /$ nri2378

48. Lehmann B, Querings K, Reichrath J. Vitamin D and skin: new aspects for dermatology. Exp Dermatol. (2004) 13:11-5. doi: 10.1111/j.16000625.2004.00257.x

49. Kawahara K, Hohjoh H, Inazumi T, Tsuchiya S, Sugimoto Y. Prostaglandin E2-induced inflammation: Relevance of prostaglandin E receptors. Biochim Biophys Acta BBA Mol Cell Biol Lipids. (2015) 1851:414-21. doi: 10.1016/j.bbalip.2014.07.008

50. Schmidt LM, Belvisi MG, Bode KA, Bauer J, Schmidt C, Suchy M$\mathrm{T}$, et al. Bronchial epithelial cell-derived prostaglandin $\mathrm{E}_{2}$ dampens the reactivity of dendritic cells. J Immunol. (2011) 186:2095-105. doi: 10.4049/jimmunol.1002414

51. Matsumoto K, Azuma Y, Kiyoki M, Okumura H, Hashimoto K, Yoshikawa $\mathrm{K}$. Involvement of endogenously produced 1,25-dihydroxyvitamin D-3 in the growth and differentiation of human keratinocytes. Biochim Biophys Acta BBA Mol Cell Res. (1991) 1092:311-8. doi: 10.1016/S0167-4889(97)90006-9

52. Gniadecki R. Stimulation versus inhibition of keratinocyte growth by $1,25-$ Dihydroxyvitamin D3: dependence on cell culture conditions. I Invest Dermatol. (1996) 106:510-6. doi: 10.1111/1523-1747.ep12343866

53. Zhang D, Peng C, Zhao H, Xia Y, Zhang D, Dong H, et al. Induction of thymic stromal lymphopoietin expression in 16-HBE human bronchial epithelial cells by 25-hydroxyvitamin D3 and 1,25-dihydroxyvitamin D3. Int J Mol Med. (2013) 32:203-10. doi: 10.3892/ijmm.2013.1353

54. Molero-Abraham M, Sanchez-Trincado JL, Gomez-Perosanz M, TorresGomez A, Subiza JL, Lafuente EM, et al. Human oral epithelial cells impair bacteria-mediated maturation of dendritic cells and render $\mathrm{T}$ cells unresponsive to stimulation. Front Immunol. (2019) 10:1434. doi: 10.3389/fimmu.2019.01434

55. Moingeon P, Batard T, Fadel R, Frati F, Sieber J, Overtvelt L. Immune mechanisms of allergen-specific sublingual immunotherapy. Allergy. (2006) 61:151-65. doi: 10.1111/j.1398-9995.2006.01002.x

56. Chinthrajah RS, Hernandez JD, Boyd SD, Galli SJ, Nadeau KC. Molecular and cellular mechanisms of food allergy and food tolerance. J Allergy Clin Immunol. (2016) 137:984-97. doi: 10.1016/j.jaci.2016.02.004

57. White AG, Wolsic CL, Campbell KL, Lavergne SN. Canine progenitor epidermal keratinocytes express various inflammatory markers, including interleukin-8 and CD40, which are affected by certain antibiotics. Vet Dermatol. (2014) 25:493-e82. doi: 10.1111/vde.12164

58. Grewe M, Gyufko K, Krutmann J. Interleukin-10 production by cultured human keratinocytes: regulation by ultraviolet B and ultraviolet A1 radiation. J Invest Dermatol. (1995) 104:3-6. doi: 10.1111/1523-1747.ep12613446

59. Tomee JFC, van Weissenbruch R, de Monchy JGR, Kauffman HF. Interactions between inhalant allergen extracts and airway epithelial cells: effect on cytokine production and cell detachment. J Allergy Clin Immunol. (1998) 102:75-85. doi: 10.1016/S0091-6749(98)70057-0

60. Asokananthan N, Graham PT, Fink J, Knight DA, Bakker AJ, McWilliam AS, et al. Activation of protease-activated receptor (PAR)-1, PAR-2, and PAR-4 stimulates IL-6, IL-8, and prostaglandin $\mathrm{E}_{2}$ release from human respiratory epithelial cells. J Immunol. (2002) 168:3577-85. doi: 10.4049/jimmunol.168.7.3577

61. Lutay N, Håkansson G, Alaridah N, Hallgren O, Westergren-Thorsson G, Godaly G. Mycobacteria bypass mucosal NF-kB signalling to induce an epithelial anti-inflammatory IL-22 and IL-10 response. PLOS ONE. (2014) 9:e86466. doi: 10.1371/journal.pone.0086466

62. Park W-J, Park B-J, Song Y-J, Lee D-H, Yuk S-S, Lee J-B, et al. Analysis of cytokine production in a newly developed canine tracheal epithelial cell line infected with H3N2 canine influenza virus. Arch Virol. (2015) 160:1397-405. doi: 10.1007/s00705-015-2395-1

63. Santoro D, Ahrens K, Marsella R, Segre M. Evaluation of antimicrobial peptides and cytokine production in primary keratinocyte cell culture from healthy and atopic beagles. Exp Dermatol. (2015) 24:317-9. doi: 10.1111/exd.12660

64. Klukowska-Rötzler J, Chervet L, Müller EJ, Roosje P, Marti E, Janda J. Expression of thymic stromal lymphopoietin in canine atopic dermatitis: thymic stromal lymphopoietin in atopic dermatitis. Vet Dermatol. (2013) 24:54-e14. doi: 10.1111/j.1365-3164.2012.01096.x

65. Thirion-Delalande C, Gervais F, Fisch C, Cuiné J, Baron-Bodo V, Moingeon P, et al. Comparative analysis of the oral mucosae from rodents and non-rodents: application to the nonclinical evaluation of sublingual immunotherapy products. PLoS ONE. (2017) 12:e0183398. doi: 10.1371/journal.pone.0183398

66. Edgar R. Gene expression omnibus: NCBI gene expression and hybridization array data repository. Nucleic Acids Res. (2002) 30:207-10. doi: $10.1093 /$ nar/30.1.207

Conflict of Interest: The authors declare that the research was conducted in the absence of any commercial or financial relationships that could be construed as a potential conflict of interest.

Copyright (c) 2020 Pelst, Höbart, Wallaeys, De Rooster, Gansemans, Van Nieuwerburgh, Devriendt and Cox. This is an open-access article distributed under the terms of the Creative Commons Attribution License (CC BY). The use, distribution or reproduction in other forums is permitted, provided the original author(s) and the copyright owner(s) are credited and that the original publication in this journal is cited, in accordance with accepted academic practice. No use, distribution or reproduction is permitted which does not comply with these terms. 